\title{
Biomechanical and hydraulic challenges for a tropical swamp forest and driftwood tree - Alstonia spatulata Blume (Apocynaceae)
}

\author{
P. Baas ${ }^{1}$, B.-J. van Heuven ${ }^{1}$, X.Y. $\mathrm{Ng}^{2} \&$ N. Vander Velde ${ }^{3}$ \\ ${ }^{1}$ Naturalis Biodiversity Center, PO Box 9517, \\ 2300 RA Leiden, The Netherlands \\ Pieter.Baas@naturalis.nl \\ ${ }^{2}$ Horticulture and Community Gardening Division, \\ National Parks Board, 1 Cluny Road, Singapore 259569 \\ ${ }^{3}$ Biological Consultant, Majuro, Republic of the Marshall Islands
}

\begin{abstract}
Rootwood and basal stemwood of Alstonia spatulata is polystyrene-like in texture and softness when dry. It has been traditionally used for pith helmets, rafters, and as cork substitute, and can be dispersed over long distances as driftwood. This driftwood is so common on the beaches across the Central Pacific that in the Marshall Islands a special traditional use of the wood for floaters or cork substitutes named wĩj has emerged. Here we describe this ultralight driftwood and the rootwood and basal stemwood of Alstonia spatulata, a tree from swamp forests of Southeast Asia. The ground-tissue is composed of very thinwalled modified fibres without tip growth and vestured pits without borders. Axial parenchyma is in narrow marginal bands, and scanty paratracheal. Vessels are narrow. Rays are extremely low and mostly uniseriate. We discuss the biomechanical and hydraulic conductivity paradox of small to medium-sized trees resting on an extremely weak and soft trunk base (at the root collar), and the parallel evolution of similar very soft woods in swamp forests of both the Old and the New World and in the Deccan fossil record of India.
\end{abstract}

Keywords. Aeschymenoxylon tertiarum, cork substitute, intrusive growth, modified fibres, polystyrene, vestured pits, wũj

\section{Introduction}

A number of years ago a very light driftwood, abundant on the beaches of the Marshall Islands attracted botanical and anthropological attention (Vander Velde \& Vander Velde, 2006; Fig. 1). The driftwood had been traditionally used by the islanders as cheap cork substitute for stoppers on liquid containers, or even to prevent prepared human corpses from leaking, as well as for floaters and cushions, under the name $w \tilde{u} j$. Over the years, the material had been sent to various wood anatomists, but a satisfactory identification consistent with its origin was not found. The tentative identification as Molongum laxum (Benth.) Pichon (Apocynaceae) from the flood plains of Venezuela by Alex Wiedenhoeft was considered unlikely for geographical reasons (Vander Velde \& Vander Velde, 2006). In Leiden we arrived at a match for wüj with root and stem collar wood of Alstonia spatulata Blume, partly through 
serendipity by "remembering" a picture in Carlquist's concise textbook Comparative Plant Anatomy (1961) in which extreme variation in secondary xylem within a plant is illustrated with root and stemwood of Alstonia spatulata taken from Ingle \& Dadswell (1953) on the woods of Apocynaceae and Annonaceae from the Pacific.

Later comparisons of the driftwood with economic botany collections in the Africa Museum in Tervuren (Tw, Belgium), the Royal Botanic Gardens Kew (Kw, England), and the Naturalis Biodiversity Center in Leiden (Lw) all labelled Alstonia spatulata or simply as "[Siamese] balsa" (Fig. 2) confirmed our identification. In the PROSEA Timber Volume 5 (1) (Lemmens \& Soerianegara, 1993) the uses of rootwood of Alstonia spatulata are listed: pith helmets, rafts, rafters for fishery and as a replacement for cork. Graefe (1934) reckoned that the rootwood was the lightest wood in the world, and Metcalfe \& Chalk (1950) reported an extremely low specific gravity (s.g.) of 0.06-0.08. Our material studied was even lighter with specific gravities of 0.04-0.05. The ordinary trunkwood, though light (s.g. c. 0.26, original observation) has more common uses for crates, tea chests, carving, plywood and carpentry (Lemmens \& Soerianegara, 1993), in common with the light wood of the more common Alstonia scholaris (L.) R.Br. belonging to the same section, Alstonia, of the genus.

The discovery of comparably light woods from flood and swamp forests in Latin America (Wiedenhoeft, 2001; Berry \& Wiedenhoeft, 2004; Berry et al., 1999) in a number of unrelated families, and in the fossil record from the K-Pg Boundary, c. $65 \mathrm{Ma}$ (Wheeler et al., 2017) invited a discussion of the biomechanical and hydraulic functioning of wood that is as light and soft as polystyrene and yet has to support the weight of the trunk and crown of medium-sized trees, and supply them with water and mineral nutrients.

Although described in some detail and compared to stemwood by Ingle \& Dadswell (1953) we found new extraordinary features that we consider worthy of publication. However, preparing this manuscript had to wait for authenticated material to become available, identified by a taxonomic specialist on the family, Dr David Middleton (Singapore), and growing in the Pasir Panjang nursery, Singapore.

\section{Materials and methods}

For comparison with the driftwood samples provided by Nancy Vander Velde (Fig. 1) we consulted reference samples from the Tervuren and Kew Xylaria (Tw and $\mathrm{Kw}$ ), labelled respectively King Leopold II (Tw 3870), possibly a gift to the King of Belgium during one of his visits to Indonesia - then still the Dutch Indies (Hans Beeckman, personal communication), and Malaya, Pierpont 49.1933, rootwood of Alstonia spatulata used for making pith helmets ( $\mathrm{Kw}$, economic botany collection). In the course of our study a large demonstration trunk (Fig. 2) in the past used for teaching in plant anatomy courses of Leiden University, and misleadingly labelled "balsa", but in anatomy totally different from Ochroma pyramidale (Cav. ex Lam.) Urb. (Mabberley, 2017) and with an even much lower specific gravity, also turned out to belong to Alstonia spatulata ("Siam Balsa"). Fresh material was collected by one 


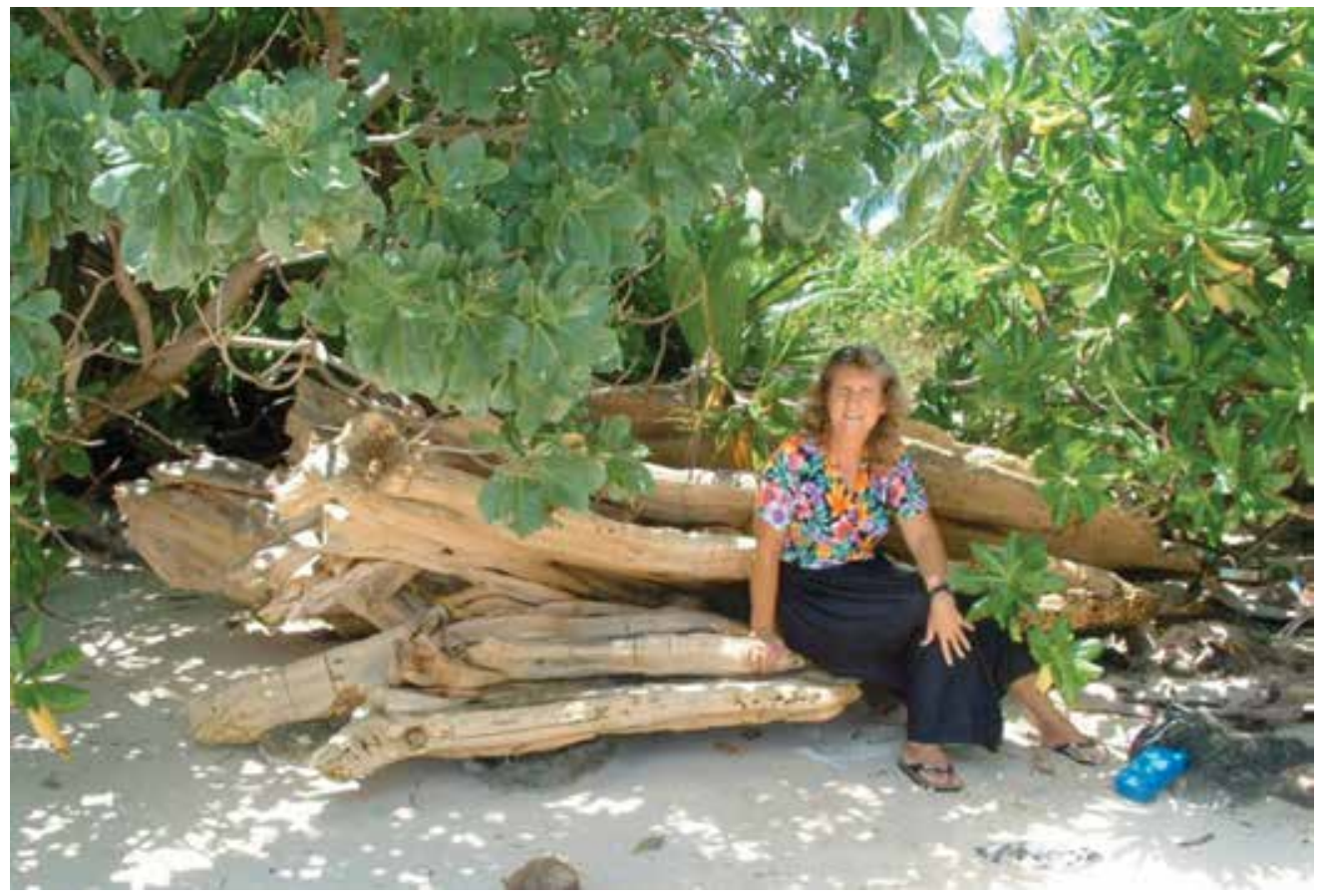

Fig. 1. Nancy Vander Velde sitting on a large driftwood specimen of Alstonia spatulata. (Photo B. Vander Velde).

of us (XYN) from a young tree of Alstonia spatulata growing in the Pasir Panjang nursery, Singapore. A herbarium voucher, $N g$ Xin Yi SING2018-793, of this tree is kept in the herbarium of the Singapore Botanic Garden (SING). Cores were taken with an increment corer (diameter $5 \mathrm{~mm}$ ) at root collar level (Fig. 3). Unfortunately, we did not succeed in obtaining authenticated wood samples from trees growing in swamp forests. This is a sad reflection on the current limitations on collecting wood samples in the wild - despite the availability of (nearly) nondestructive sampling methods such as increment coring or taking samples near the cambium with the so-called Trephor tool (Rossi et al., 2006).

Transverse, radial and tangential sections of all samples were cut on a Reichert sliding microtome, or by hand with one-sided razor blades, stained with safranin/ hematoxylin and mounted in Canada balsam. Unstained freehand sections were also observed directly in air. Macerations were obtained by incubating wood slivers in $30 \%$ hydrogen peroxide and glacial acetic acid at $60^{\circ} \mathrm{C}$ for 12 hours, rinsed in water, stained in aqueous astra blue and mounted in glycerin-jelly.

Small cubes of the driftwood, cut to expose the transverse and radial and tangential planes were sputter-coated with gold and observed in a JEOL JSM5300 SEM. 


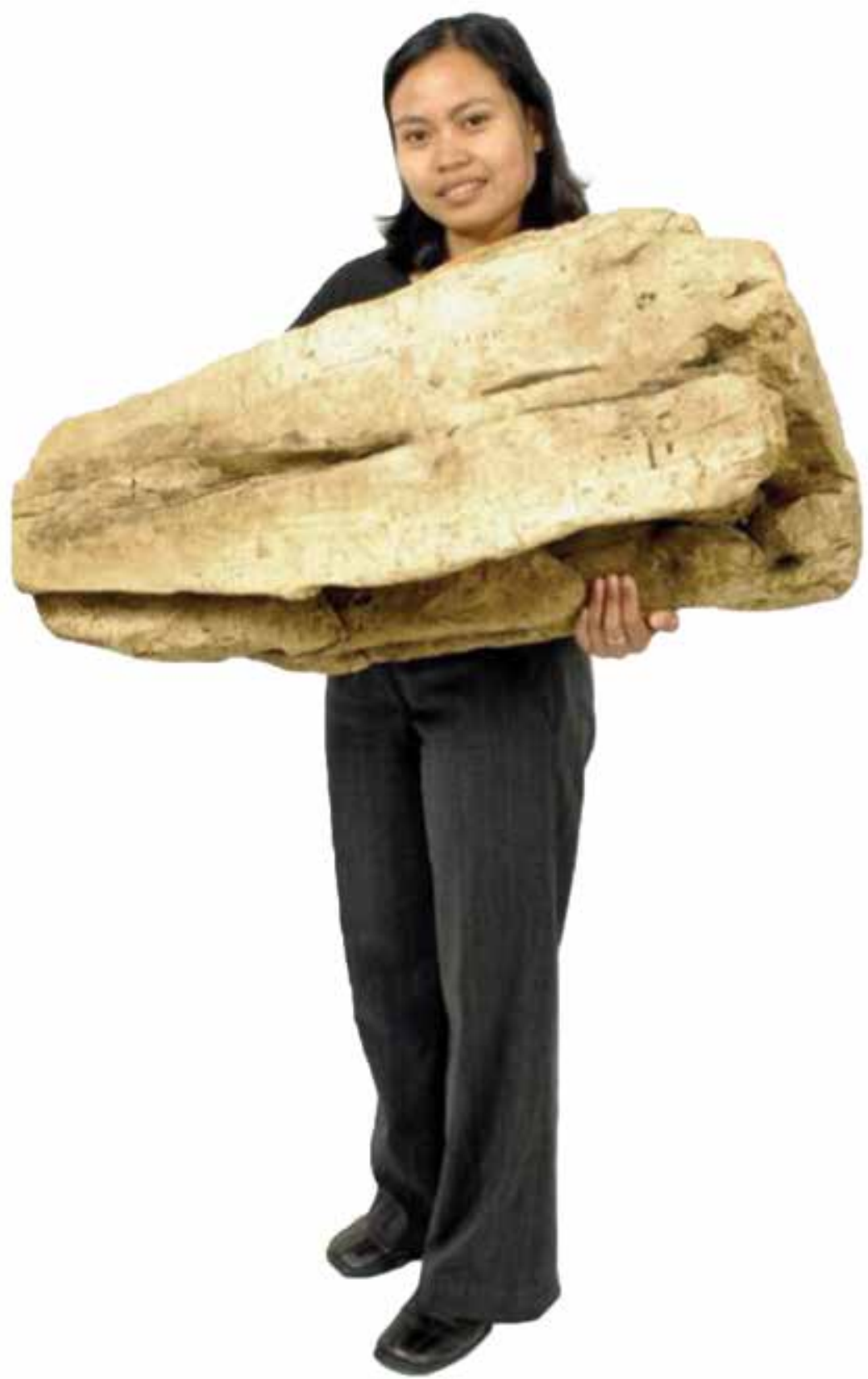

Fig. 2 Sumi Yuami, holding the Siam Balsa teaching specimen. Basalmost part of the trunk right, more distal part to the left. (Photo: B. Kieft). 


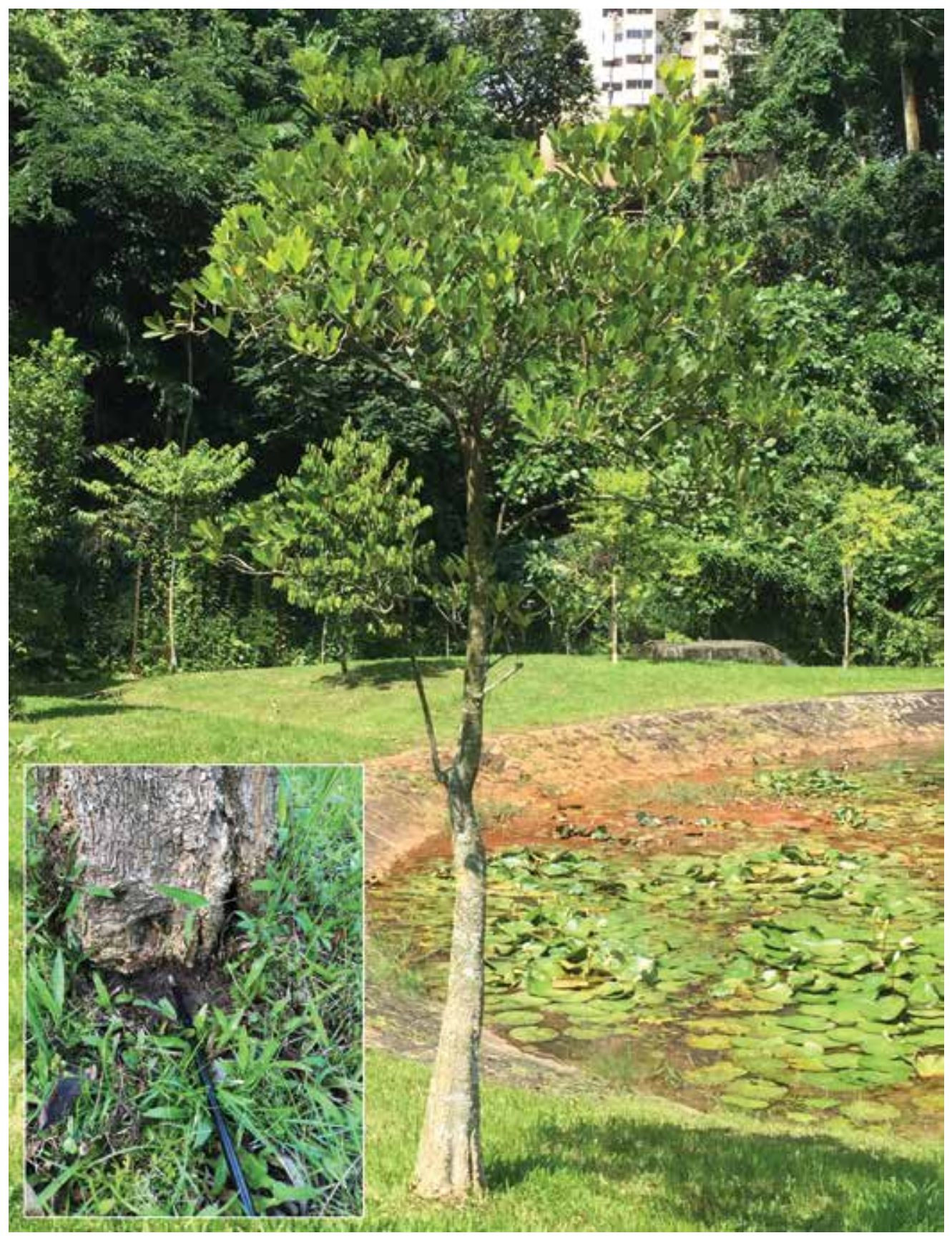

Fig. 3. Young tree of Alstonia spatulata grown in the Pasir Panjang nursery, Singapore. Inset: Trunk base with increment corer indicating place of sampling at the root collar. (Photo: X.Y. Ng). 


\section{Results}

Description of the driftwood samples (Fig. 4, 5, 6A)

Wood seemingly vessel-less, but diffuse-porous with infrequent vessels (much less than one per $\mathrm{mm}^{2}$ ), solitary and in radial multiples of 2-3 or small clusters, often associated with the seemingly marginal parenchyma bands (Fig. 4 and Fig. 5). Vessels angular in outline and mostly of the same size and shape as the ground tissue cells but with less extremely thin walls (c. 3-5 $\mu \mathrm{m}$ for double wall thickness). Perforations simple in slightly inclined walls; sometimes in lateral walls - suggesting the presence of perforated ray cells. Inter-vessel pits vestured, alternate 5-7 $\mu \mathrm{m}$ in horizontal diameter, with oval to slit-like, often coalescent apertures. Vessel-ray pits of similar shape and size.

Ground tissue of extremely thin-walled elongate cells ("modified fibres"), square to rectangular or hexagonal in TS, c. 50-90 × 70-100 $\mu \mathrm{m}$, weakly fusiform with triangular tips as seen in TLS, c. 300-600(-700) $\mu \mathrm{m}$ long, more or less rectangular in RLS and without apparent tip growth typical of the trunkwood fibres (Fig. 4B, 5B, 6A). Double walls extremely thin (c. $1.5 \mu \mathrm{m})$. With numerous apparently simple pits in the radial walls, $5-8 \mu \mathrm{m}$ in diameter, with finely reticulate vestures (Fig. 5B-D). Pit borders absent. Softrot cavities often present at c. 45-60 degrees to the vertical axis (suggesting that an $\mathrm{S}_{1}$, rather than an $\mathrm{S}_{2}$ layer constitutes the bulk of the cell wall).

Parenchyma scanty paratracheal and in seemingly marginal bands one to four cells thick (Fig. 4A, 5A). Rarely also diffuse-in-aggregates. In strands of (2-)4-8 cells. Very infrequent, chambered $\mathrm{Ca}$-oxalate crystals observed in one sample.

Rays mostly uniseriate, occasionally biseriate, and very low, 1-6(-10) cells high (Fig. 4B), composed of strongly procumbent cells only. Radial latex canals present in fusiform rays in very low frequency (Fig. 5E). Missing from several driftwood samples.

Intercellular spaces between ground tissue cells common (Fig. 5A).

Note that the above description is based on eight driftwood samples from the Marshall Islands collected by NVV. All these samples vary greatly in diameter (from $1-15 \mathrm{~cm}$ ), without strongly affecting the quantitative values for cell diameter and cell length or ray height and composition. Only very near the primary root-stele, cells are significantly narrower, and rays may contain some square to upright cells. It is therefore highly likely that all driftwood samples belong to the same species.

\section{Comparisons with museum specimens}

The above description perfectly fits that of the museum rootwood specimens of Alstonia spatulata from the Kew and Tervuren collections and the rootwood description and illustration in Ingle \& Dadswell (1953), as well as the basalmost part of the Siam Balsa trunk specimen from the Leiden teaching collection.

\section{Comparison with the living tree trunk base (Fig. 6B-D)}

In qualitative features the wood cored from the root collar of the very young Alstonia spatulata tree from Singapore agrees well with that of the driftwood and the museum 


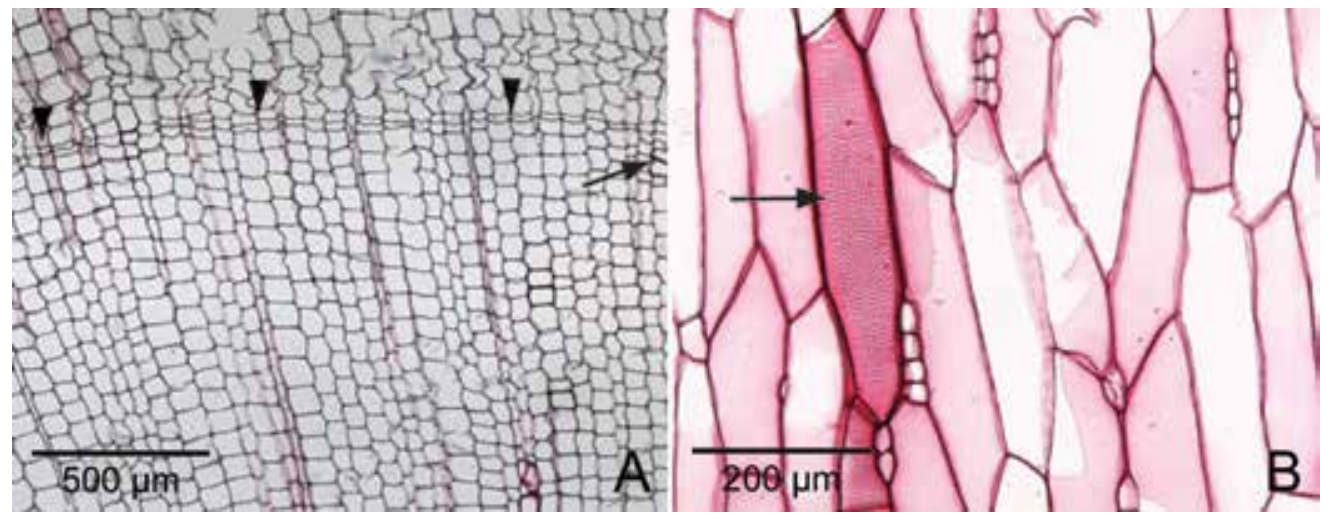

Fig. 4. Light micrographs (LM) images of driftwood samples. A. LM of transverse section showing seemingly homoxylous wood. Vessel is indicated with an arrow; seemingly marginal parenchyma band by arrowheads B. LM of TLS. Note low uniseriate rays and ground tissue fibres of same shape and size as vessel element (arrow). (Photos: B.J. van Heuven).

rootwood samples and basalmost part of the Leiden trunk sample. However, in quantitative features there are differences: ground tissue fibres $(50 \times 60 \mu \mathrm{m})$ and vessels are narrower $(50-80 \mu \mathrm{m})$, rays are more frequently biseriate or even triseriate and radial laticifers are more common (c. $3 / \mathrm{mm}^{2}$ in TLS) than in any of the driftwood and museum specimens $\left(<0.1 / \mathrm{mm}^{2}\right)$, or in the xylarium (Lw) trunkwood samples $\left(0.1-2 / \mathrm{mm}^{2}\right)$ [see below].

\section{Comparison with trunkwood (Fig. 7A, B)}

Sidiyasa (1998) gave a detailed account of the stemwood anatomy of Alstonia, including $A$. spatulata. We based our comparison on his descriptions and sections, which are preserved in the Lw collections of the Naturalis Biodiversity Center. Normal trunkwood of Alstonia spatulata differs from the basalmost root collar wood and rootwood in a strong divergence of vessel element and fibre dimensions (vessel diameter 100-110 $\mu \mathrm{m}$ versus fibre diameter 25-40 $\mu \mathrm{m}$; vessel element length 720 $\mu \mathrm{m}$ versus fibre length $1250 \mu \mathrm{m}$; double vessel wall thickness $7-10 \mu \mathrm{m}$; double fibre wall thickness 3-5 $\mu \mathrm{m}$ ). Maximum ray height about twice as high as in rootwood (up to 24 cells high). Rays mostly uniseriate, but biseriate rays not uncommon. Laticifers absent (one sample) to infrequent ( 2 other samples, $0.1-2$ per $\mathrm{mm}^{2}$ in TLS). Alstonia spatulata belongs to the light timber section Alstonia and within that section it stands out because of its narrow rays (1-2-seriate) which are mostly $1-3(-4)$-seriate in the other species, although there is overlap with the range in A. pneumatophora Baker ex Den Berger.

\section{Gradual variation from trunk base to breast height}

The wood samples studied by Sidyasa (1998) were from forestry inventories in Indonesia (Kalimantan and Papua) and presumably all from breast height, or an equivalent height above any buttresses, that are present in part of the trees. The Siam Balsa trunk 


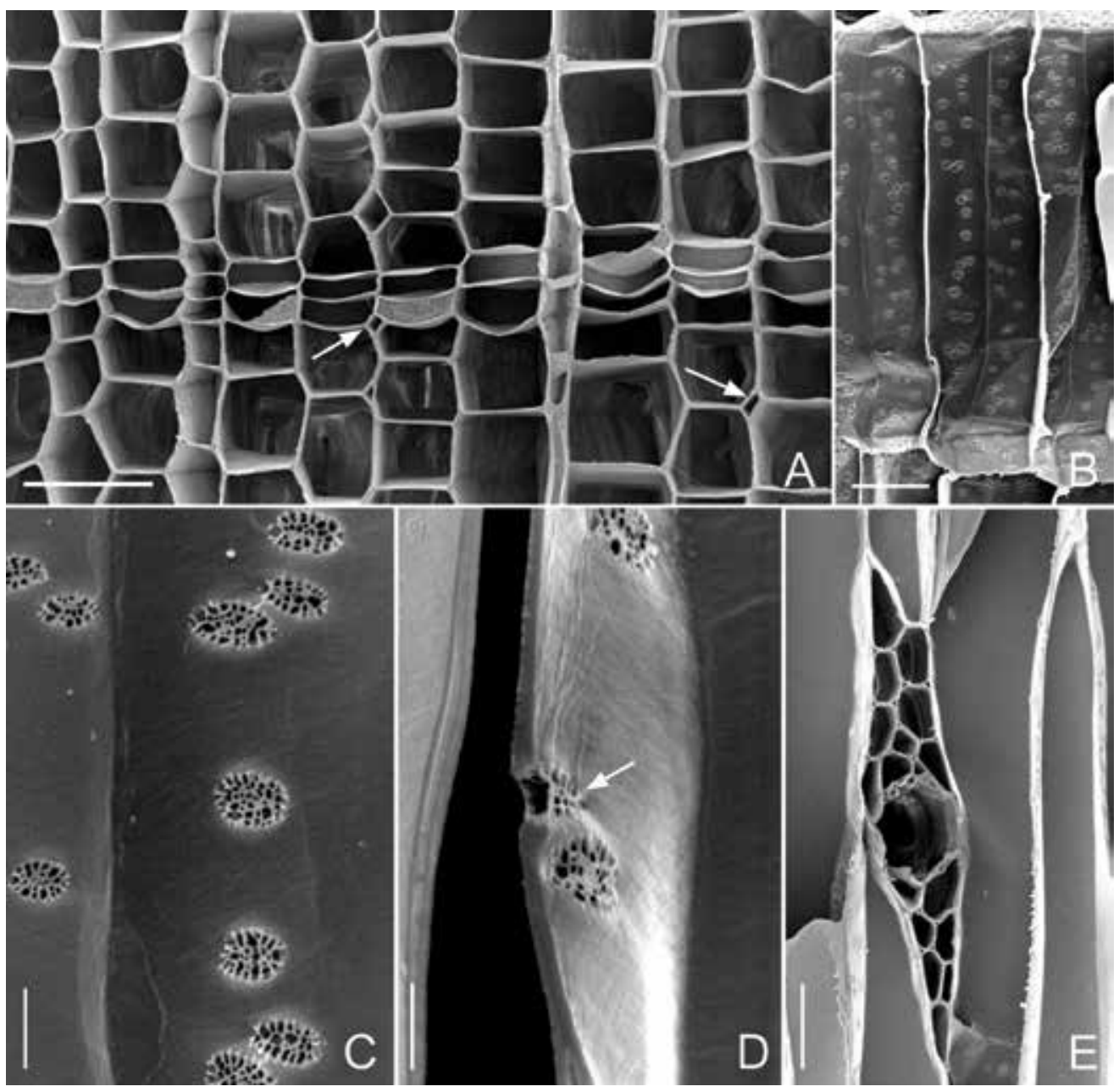

Fig. 5. A. Transverse surface, SEM (Scanning Electron Microscopy) images of ground tissue, marginal parenchyma and narrow ray, note small intercellular spaces between the ground tissue cells (arrows). B. Radial surface, SEM showing modified fibres with vestured pits in radial walls, and lack of intrusive tip growth. C \& D. SEM details of vestured fibre pits in surface view and in longitudinal section. Arrow in $5 \mathrm{~d}$ points to vestures overlaying pit cavity. E. Radial laticifer seen in TLS. - Scale bar in $\mathrm{A}=100 \mu \mathrm{m}$; in $\mathrm{B}, \mathrm{E}=50 \mu \mathrm{m}$; in $\mathrm{C}=10 \mu \mathrm{m}$, in $\mathrm{D}=5 \mu \mathrm{m}$. (Photos: B.J. van Heuven).

sample (Lw, Fig. 2) is about $1 \mathrm{~m}$ long. Its basal part shows a primary rootwood stele, and its distal end a typically cylindrical primary stem xylem surrounding a pith. The secondary xylem of the distal end of that sample is intermediate between the rootwood and normal trunkwood: vessels are clearly differentiated from the fibres (diameters 110 versus $40 \mu \mathrm{m}$ ), and occur in higher frequency than in the rootwood at $3-5 / \mathrm{mm}^{2}$ (which is only marginally less frequent than $6-7 / \mathrm{mm}^{2}$ in normal trunkwood); fibres show distinct intrusive tip growth in radial and tangential longtitudinal sections, but are still much shorter than in normal trunkwood; mean length c. 700 versus $1100 \mu \mathrm{m}$. 


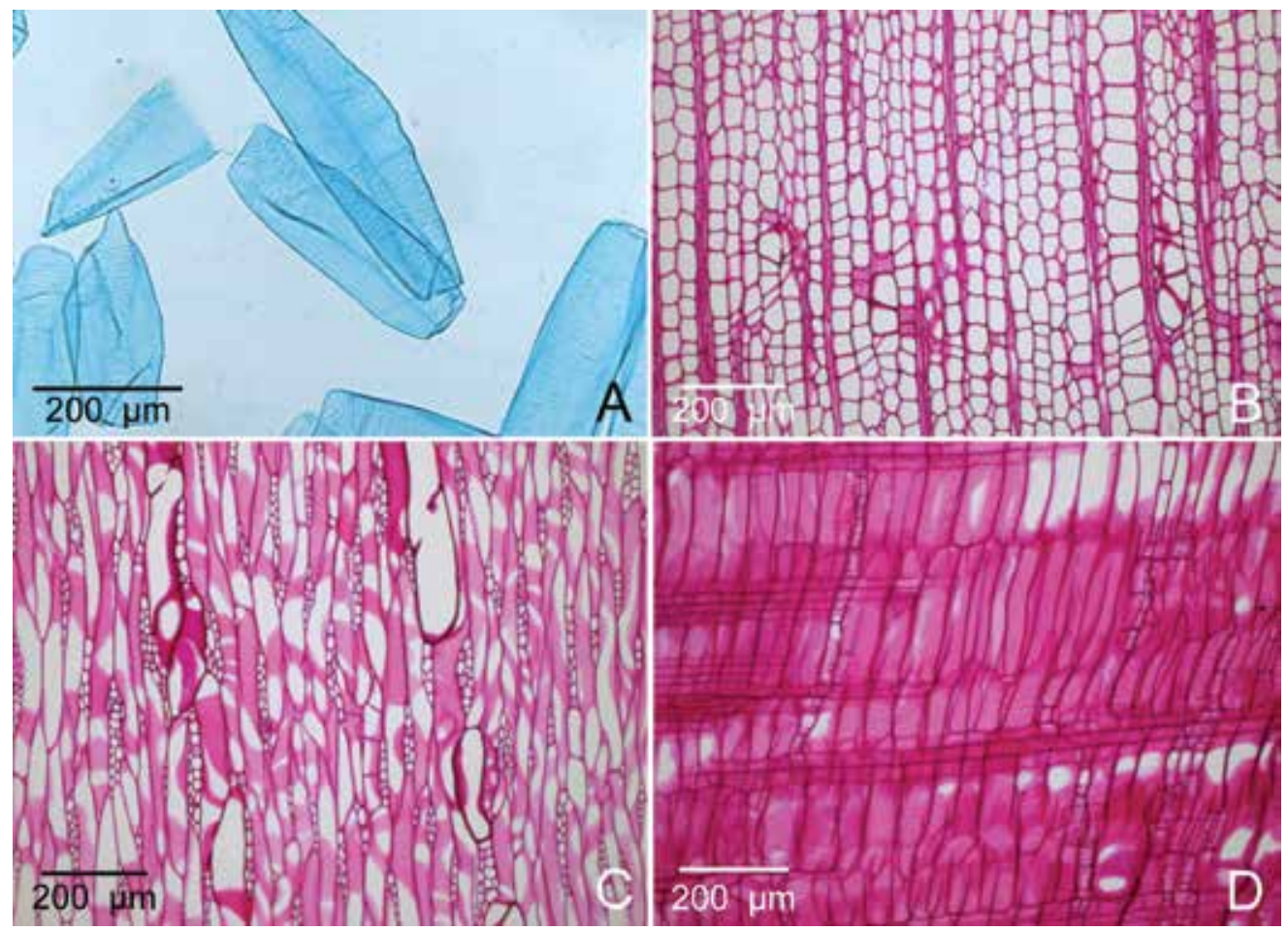

Fig. 6. Driftwood and reference samples of Alstonia spatulata. A. Maceration of driftwood showing modified fibres without tip growth. B-D. TS, TLS and RLS of secondary xylem at the root collar of the young tree cultivated in Singapore (cf. Fig. 3). (Photos: B.J. van Heuven).

\section{Discussion}

\section{Identity and provenance of the driftwood samples}

There is no doubt that the driftwood in the Marshall Islands, traditionally used under the name wiuj by the local population, is conspecific with the museum specimens labelled Alstonia spatulata rootwood, from Peninsular Malaysia and Indonesia, and with the basalmost trunkwood of the demonstration specimen of Siam Balsa (= A. spatulata). When comparing the rootwood with the mature stemwood of vouchered herbarium samples, Alstonia spatulata is also a likely candidate for species identification due to its extremely narrow rays. Notably, the basalmost stemwood from a young unambiguously identified Alstonia spatulata tree grown in Singapore's Pasir Panjang nursery shows the greatest difference with the driftwood: it has smaller ground tissue cells, somewhat wider rays, and more frequent radial laticifers than both the driftwood and the commercial, unvouchered specimens from Kew, Tervuren and Leiden. More research on additionally collected material from natural swamps is needed to see whether all driftwood specimens are within the natural variability of Alstonia spatulata. We believe it probably is: the core taken from the root collar shows signs of traumatic tissue in the wood, which might indicate mechanical or other 
damage in its planting and replanting history. Increased formation of laticifers as a biological defence, and reduction in size of cambial derivatives, could well have been a response to this trauma (cf. Baas et al., 1984 on dwarf growth, often also induced by trauma). There is considerable infraspecific variation in the frequency of laticifers in trunkwood - expressed as number per square $\mathrm{mm}$ in tangential sections. In the Leiden slide collection, we found this to vary between $0.1-2.0$ in both Alstonia pneumatophora (6 specimens) and A. scholaris (10 specimens), and between zero and c. 1.0 in $A$. spatulata (3 specimens). Alstonia spatulata has a wide natural distribution in lowland swamp forests throughout Thailand, Laos, Cambodia, Myanmar, Vietnam, Malaysia, Brunei, Singapore, Indonesia and Papua New Guinea. The Marshall Islands are far removed from any of these provenances, although New Guinea would be the closest at a distance of about $3000 \mathrm{~km}$. Ocean currents are complex in this part of the Pacific and there is no way of speculating from which precise provenance the driftwood samples originated (Vander Velde \& Vander Velde, 2006).

\section{Other examples of very light swamp forest woods}

Berry et al. (1999), Wiedenhoeft (2001, quoted from Berry \& Wiedenhoeft, 2004), and Berry \& Wiedenhoeft (2004) have reported on exceptionally light woods of Anaxagorea inundata P.E.Berry \& R.B.Mill (Annonaceae) and Micranda inundata P.E.Berry \& Wiedenh (Euphorbiaceae) growing in seasonal flood plains in Venezuela which strongly recall the syndrome of basal-most trunkwood and rootwood of Alstonia spatulata. Common trends are very wide and relatively short fibres, with densely pitted lateral walls, rays narrower and dry wood specific gravity much lower than in terra firma relatives. According to these authors, representatives subject to flooding in Venezuela of other families such as Apocynaceae, Bombacaceae, and Sapotaceae also have species with very light wood (s.g. c. 0.20 , still 3 to 5 times heavier than our driftwood).

The secondary xylem of the swollen basal stem portions of Leptospermum crassipes Lehm. (Myrtaceae), from swamps in West Australia, also recalls that of Alstonia spatulata, with its ground tissue of thin-walled vascular tracheids similar in shape and size to the vessel elements (Baas, 1977).

Wheeler et al. (2017) re-described a remarkable look-alike of Alstonia spatulata rootwood from the fossil record of India's Deccan Traps at the KPg boundary (67-64 Ma) - Aeschynomenoxylon tertiarum (Prakash) Müller-Stoll \& Mädel with equally short, modified fibres (Fig. 7C-D), marginal parenchyma, very low uniseriate rays, and inconspicuous vessels. The main difference with Alstonia is in the large and simple vessel-ray pits of the fossil, suggesting a different botanical affinity than either Apocynaceae or Fabaceae. The name Aeschynomenoxylon was revealed to definitely be a misnomer, because Aeschynomene is characterised by marginal fibre bands, not by parenchyma bands as in Alstonia spatulata and the fossil. Interestingly the shrubby, aquatic pith plant Aeschynomene spp. is - as far as we are aware - the only other species yielding raw material for the manufacturing of pith helmets. We suggest that Aeschynomenoxylon tertiarum represents basal stemwood or rootwood of a swamp forest tree of uncertain botanical affinities. 


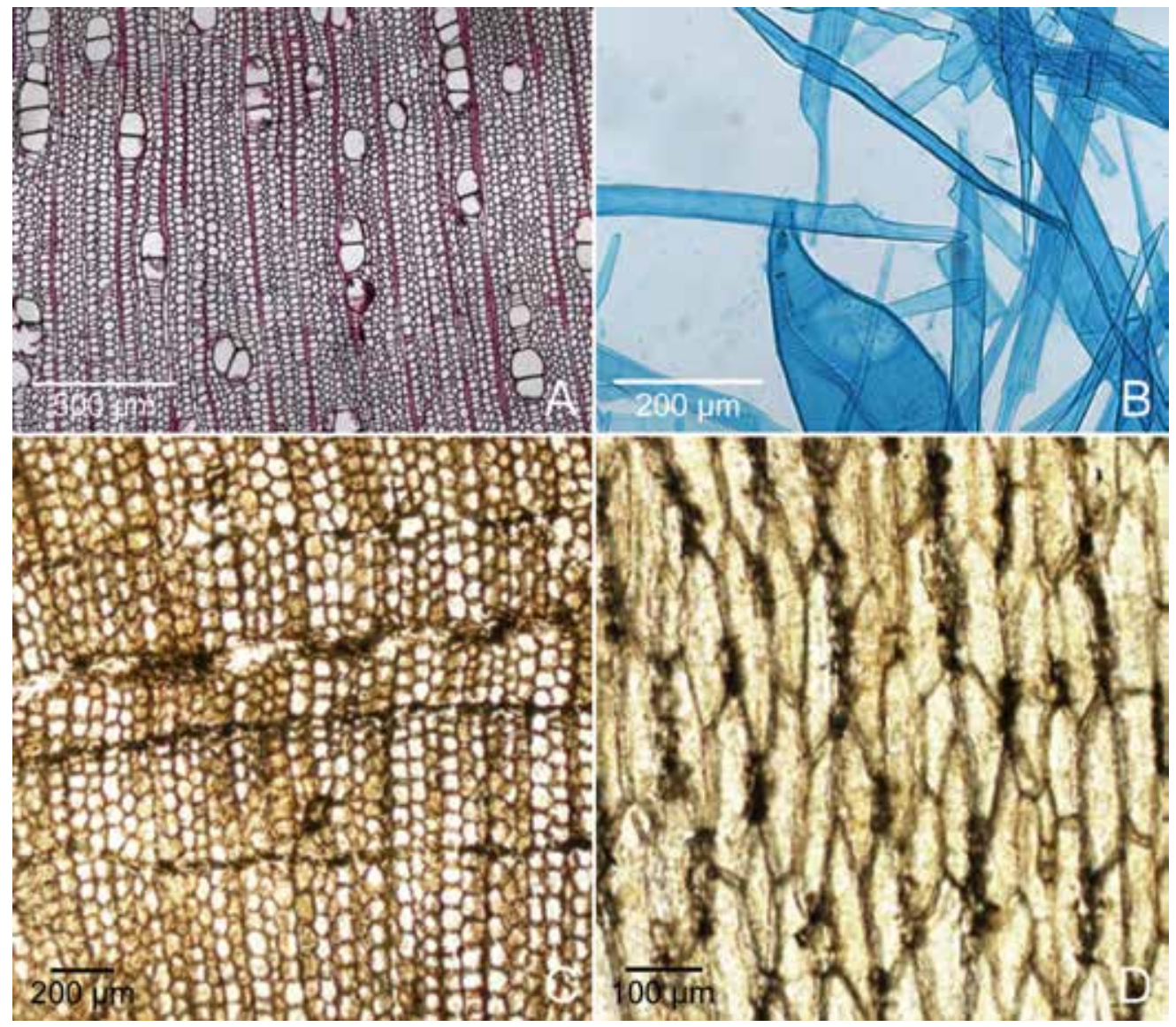

Fig. 7. A \& B. Normal trunkwood of Alstonia spatulata. A. Transverse section. B. Maceration showing wide vessel element and narrow fibres with tip growth. C \& D. TS and TLS of fossil driftwood look-alike Aeschynomenoxylon tertiarum from the Deccan Traps in India (Photos: A \& B, B.J. van Heuven; C \& D from Wheeler et al., 2017, used with permission from the editors of the IAWA Journal).

Obviously, the parallel wood anatomical trends in tree species from swamps or inundation forests makes wood identification of these ultralight woods more difficult, but as shown above not entirely impossible. Parallels in structural adaptation to waterlogged or seasonally flooded conditions do, however, beg the question of functional significance of the syndrome described here for Alstonia spatulata.

\section{Functional implications}

Two questions immediately arise when reflecting on the unusual basal stem and rootwood of Alstonia spatulata. 1) How can it perform its hydraulic functions, and 2) Is the very light and soft wood of the trunk base with wide, short, and blunt fibres strong enough to support a small- to medium-sized tree with a normal (thus quite heavy) tree crown? 
All water transpired by the leaves in the tree crown has to pass through the rootwood with the basal-most trunkwood at the root collar as bottleneck. It seems evident that the narrow vessels, present in extremely low densities (less than $1 / \mathrm{mm}^{2}$ ) both in the rootwood and root collar do not provide sufficient capacity for water transport at times of maximum leaf transpiration. We therefore propose that all modified fibres must serve in conduction, much in the same way as earlywood tracheids do in coniferous trees. With their frequent and quite large lateral wall pits, protected from pit membrane aspiration damage by their conspicuous vestures (Fig. 5D) these modified fibres are probably very efficient in water conduction.

The question of mechanical strength is more difficult to understand. Absence of fibres with long overlapping tips thanks to intrusive growth, extremely thin-walled cells with a low microfibrillar slope $\left(S_{1}\right.$ the dominant cell wall layer, $S_{2}$ probably absent or mechanically insignificant) and extreme softness suggest a very weak stembase and root system. Mechanical demands on roots are relatively low, but the stembase at the root collar carries all the weight and lateral forces that might arise in windy conditions. Chapotin et al. (2006) found that the very light weight wood of Baobab trees (Adansonia spp.) could still be mechanically effective thanks to the high volume percentage of turgescent parenchyma cells, remaining alive as much as $35 \mathrm{~cm}$ away from the cambium. For Alstonia spatulata that mechanism, however, seems not to be available because the ground tissue fibres are dead, and the living axial and ray parenchyma cells account for only a very low percentage of the wood volume. Perhaps Alstonia spatulata is a very weak tree, prone to mechanical failure near the root collar. Corner (1978) in his account of the fresh-water swamp forest of South Johore and Singapore, gives a vivid portrayal of numerous trees floating past his boat during a flood caused by heavy rains in 1932. Whether these included a disproportional number of Alstonia spatulata trees growing in these swamps we do not know. On herbarium labels Alstonia spatulata is often described from secondary vegetation (Sidyasa, 1998), suggesting fast growth and high turnover. Mechanical tests are obviously needed to know which forces the stem base is subjected to in waterlogged situations.

In their discussion of the functions of the light woods of two species from blackwater riverbanks in Venezuela, Berry et al. (1999) and Berry \& Wiedenhoeft (2004) also considered the possibility of aerenchymatous and hydraulic functions of the thin-walled, densely pitted ground tissue fibres. We do not think that cell morphology and wall thickness have a function in aeration, but we did find narrow but extensive intercellular spaces between the modified fibres (Fig. 5A) and other cells, which probably are relevant during anoxic waterlogged conditions in the soil to keep the living axial and ray parenchyma cells aerated.

\section{Conclusion}

The ultralight rootwood and basalmost stemwood of Alstonia spatulata is a significant component of the driftwoods landing on the shores of the Marshall Islands. The wood seems optimally constructed for water transport in the living tree. However, how this 
weak wood can fulfil its mechanical functions in the living tree remains a mystery, inviting future research involving field work in notoriously collector-unfriendly swamp forest conditions. Such research could also clarify whether the growth periodicity marked by the seemingly marginal parenchyma bands in the rootwood coincides with seasonal flooding.

DEDICATION AND ACKNOWLEDGEMENTS. We dedicate this paper to Prof. Dr. hon. causa David J. Mabberley, on the occasion of his 70th birthday in 2018. One of us (PB) used the subject of this totally serendipitous study as an example in his annual lecture in David's popular international course of Economic Botany at Leiden University and Naturalis Biodiversity Center (previously Rijksherbarium) taught from 1994-2018.

We wish to thank Dr Hans Beeckman (Tervuren) and Dr Peter Gasson (Kew) for providing reference samples and important background information; Dr David Middleton (Singapore) and Prof. Karl Niklas (Cornell) for, respectively, expert advice on Alstonia systematics and biomechanics.

\section{References}

Baas, P. (1977). The peculiar wood structure of Leptospermum crassipes Lehm. (Myrtaceae). IAWA Bull. 1977/2: 25-30.

Baas, P., Lee Chenglee, Zhang Xinying, Cui Keming \& Deng Yuefen (1984). Some effects of dwarf growth on wood structure. IAWA Bull., n.s. 5: 45-63.

Berry, P.E. \& Wiedenhoeft, A.C. (2004). Micranda inundata (Euphorbiaceae), a new species with unusual wood anatomy from black-water river banks in Southern Venezuela. Syst. Bot. 29: 125-133.

Berry, P.E., Miller, R.B. \& Wiedenhoeft, A.C. (1999). A new light-wooded species of Anaxagorea (Annonaceae) from flooded black-water shrublands in Southern Venezuela. Syst. Bot. 24: 506-511.

Carlquist, S. (1961). Comparative Wood Anatomy. New York: Holt, Rinehart \& Winston.

Chapotin, S.M., Razanameharizaka, J.H. \& Holbrook, N.M. (2006). A biomechanical perspective on the role of large stem volume and high water content in Baobab trees (Adansonia spp.; Bombacaceae). Amer. J. Bot. 93: 1251-1264.

Corner, E.J.H. (1978). The Freshwater Swamp-Forest of South Johore and Singapore. Gard. Bull. Suppl. 1. Singapore: Singapore Botanic Gardens, Parks \& Recreation Department.

Graefe, E. (1934). Das leichteste Holz. Umschau 38: 170-171.

Ingle, H.D. \& Dadswell, H.E. (1953). The anatomy of the timbers of the southwest Pacific area II. Apocynaceae and Annonaceae. Austral. J. Bot. 1: 1-26.

Lemmens, R.H.M.J. \& Soerianegara, I. (1993). Plant Resources of South-East Asia 5(1), Timber Trees - Major commercial timbers. Leiden: Backhuys Publishers.

Mabberley, D.J. (2017). Mabberley's Plant-Book, $4^{\text {th }}$ ed. Cambridge: Cambridge University Press.

Metcalfe, C.R. \& Chalk, L. (1950). Anatomy of the Dicotyledons. Oxford: Clarendon Press.

Rossi, S., Anfodillo, T. \& Menardi, M. (2006). Trephor: a new tool for sampling microcores from tree stems. IAWA J. 27: 89-97. 
Sidiyasa, K. (1998). Taxonomy, phylogeny, and wood anatomy of Alstonia (Apocynaceae). Blumea, Suppl. 11: 1-230.

Vander Velde, N. \& Vander Velde, B. (2006). Catching the drift: impacts of Oceanic drift material in the Marshall Islands. Micrones. J. Humanities Soc. Sci. 5: 431-449.

Wheeler, E.A., Srivastava, R., Manchester, S.R. \& Baas, P. (2017). Surprisingly modern Latest Cretaceous-earliest Paleocene woods from India. IAWA J. 38: 456-542.

Wiedenhoeft, A.C. (2001). Preliminary wood anatomical characterization of some lightwooded species growing in seasonally inundated Venezuelan Igapo forest. Master's thesis. University of Wisconsin-Madison, USA. 